\title{
The Complexity of Nationalism in Azerbaijan
}

\author{
Yoko Hirose ${ }^{1}$ \\ ${ }^{1}$ Faculty of Policy Management, Keio University, Japan. \\ Correspondence: Yoko Hirose, Faculty of Policy Management, Keio University, Japan.
}

Received: February 29, 2016

Accepted: March 11, 2016

Available online: April 8, 2016

doi:10.11114/ijsss.v4i5.1531

URL: http://dx.doi.org/10.11114/ijsss.v4i5.1531

\begin{abstract}
This article examines recent manifestations and trends of Azerbaijani nationalism, highlighting their complexity as they have evolved within regional and international contexts as expressions of Azerbaijani identity. It argues that although the Nagorno-Karabakh conflict between Azerbaijan and Armenia in the 1990s was instrumental in invoking and strengthening Azerbaijani nationalism, more recent manifestations of nationalism have been varied and responsive to domestic as well as international influences. These influences include the de-russification of Azerbaijani names, which began toward the end of the Soviet era, and the development of national movements aimed at promoting the country's image internationally. One means by which to achieve this latter goal has been record-setting, which has included the creation of the world's largest national flag, prioritization of sporting excellence and attempts to host major international sporting and other events, and grandiose construction of buildings, pipelines, and communication and transportation networks. The Azerbaijani diaspora has also been active in promoting an Azerbaijani identity in opposition to Armenia. At the regional level, expressions of Azerbaijani nationalism have caused apprehension within Iran that Iranian Azerbaijanis might participate in these movements. Diplomatic efforts have been aimed at achieving balance, especially in Azerbaijani relations with Russia, Turkey, Iran, China, and the West. The article concludes that Azerbaijani nationalism is currently based on a weak economic foundation of extravagance enabled by oil and gas wealth. It recommends economic diversification, as well as a rethinking of Azerbaijani nationalism policy aimed toward fostering national identity in a less costly manner.
\end{abstract}

Keywords: Azerbaijan, nationalism, Nagorno-Karabakh conflict, diaspora

\section{Introduction}

\subsection{Defining Nationalism}

Azerbaijani nationalism is difficult to define or explain because of its complexity and its diverse domestic and international influences. Moreover, nationalism is itself a vague concept. According to the Merriam-Webster dictionary, nationalism entails feelings of loyalty and devotion toward a nation, and especially a sense of national consciousness. This leads to the exaltation of one nation above all others and the promotion of its culture and interests over those of other nations or supranational groups (http://www.merriam-webster.com/dictionary/nationalism).

\subsection{Azerbaijani Nationalism: A Historical Background}

Azerbaijan's history as a nation has been brief. Following its independence in 1918, the Azerbaijan Democratic Republic (ADR) was constituted. However, from 1920 to 1991, the country was incorporated into the Soviet Union. Thus, there was little time to develop a sense of Azerbaijani nationalism. Not small people, who experienced the Soviet regime ascribed to a Soviet identity and considered Moscow as their second home. (Note 1).

However, following the collapse of the USSR, a strong nationalistic base, promoted by the people and government of Azerbaijan, was required to build a viable sovereign state.

Some nationalistic movements existed even during the Soviet period, although they were limited in terms of their capacity and scale. These were mainly constituted by the intelligentsia, especially from the late 1960s to the early 1970s. During this period, Azerbaijani nationalism was notably affected by Turkish and Iranian histories and cultures, and Islamic heritage. However, such movements were banned during the Soviet era.

Azerbaijani nationalism was later revived by perestroika and the Nagorno-Karabakh conflict (hereafter, NKC) with the Armenians. (Note 2). 
Nationalistic movements such as the Popular Front spread from Estonia to many of the Soviet republics in the wake of perestroika. Subsequently, the Baku Scientist Club established the Azerbaijan Popular Front (APF) during the summer of 1988. Despite opposition from the Communist Party, the movement continued to grow, not only because of perestroika, but also largely because of the NKC. On July 16, 1989, the APF held its founding congress and Abulfaz Elchibey was elected as the chairman of its executive board. The APF's main members were nationally conscious intellectuals and elites with shared nationalistic and secular goals. Similar to the Baltic Popular Fronts, the APF demanded greater economic, social, and political sovereignty for Azerbaijan and more local decision-making power, as well as control over Azerbaijan's national resources.

In addition, the traumas inflicted by the NKC that created many victims, refugees, and internally displaced persons (Bolukbasi, 2011; Ohannes, 2013; Hirose, 2006, 2007; Demirtepe \& Laciner, 2004) prompted the development of a strong sense of nationalism among Azerbaijanis.

The reinforcement of nationalism among those who sustain heavy losses through conflict or war appears to be a common phenomenon throughout history. The occurrence of "Black January" in 1990, and Russia's support of Armenia during the NKC fueled anti-Russian sentiment among Azerbaijanis. (Note 3).

Azerbaijani hostility toward Armenians, attributed to the NKC, has evidently strengthened Azerbaijani nationalism. However, over two decades have passed since the NKC ceasefire was declared in 1994, and while the conflict still features in the Azerbaijani media, it is fading from general consciousness. Consequently, other manifestations of Azerbaijani nationalism are assuming prominence. In recent years, the influence of Azerbaijani nationalism has extended into Iran, where many Azerbaijanis currently reside.

This paper focuses on recent manifestations of Azerbaijani nationalism. However, before discussing these, it is important to understand and situate Azerbaijani nationalism within the country's authoritarian political context.

\subsection{Authoritarianism versus Democratization: The Context of Nationalism}

Azerbaijan's political regime since the Heydar period has been criticized for its authoritarianism by the international community, especially by organizations advocating human rights, free speech, and democratization. The current regime is also the first and only hereditary regime of the former USSR. However, notwithstanding international criticism, Azerbaijanis have shown a preference for authoritarianism over democracy, likely because of the value they place on stability. The extreme confusion caused by the NHK and the collapse of the former USSR has fostered conservatism among the Azerbaijani people. Many individuals describe this period as being very sad and difficult, professing a desire for stability. Additionally, the politics and legacy of Azerbaijan's second president, Abulfaz Elchibey, remain highly salient, if not traumatic, in the collective memory of Azerbaijanis. Elchibey supported democracy and sought to transform Azerbaijan into a democratic country. However, his policies also entailed forging close relations with Turkey and the West, while cutting off ties with Russia and Iran. This policy angered Russia, which then took the side of Armenia during the NHK. This development was the main cause of Azerbaijani defeat and the current territorial control, which the Azerbaijanis term "occupation." In addition, people remember this as a time of food scarcity. For example, many could not procure bread, even after standing in line from 5:00 am.

The region has been rocked by revolutions, including the Rose Revolution in Georgia in 2003, the Orange Revolution in Ukraine in 2004, the Tulip Revolution in Kyrgyz in 2005, and the Maidan Revolution in 2013 in Ukraine. While these initially appeared promising, they ultimately failed. Having observed these failed revolutions in close proximity, Azerbaijanis tend to view democratization as undermining stability. Consequently, they do not feel that democratization will be an effective solution for the country's problems, and continue to support the Aliyev regime because of the stability it has brought to Azerbaijan.

\section{Recent Manifestations of Azerbaijani Nationalism}

As mentioned above, while the NKC prompted Azerbaijani nationalism, the synergetic combination of people's perceptions and the activities of certain organized movements have effectively contributed to changing expressions of nationalism.

This paper provides some examples aimed at stimulating reflection on these movements. In the sections below, I discuss the move toward de-russification of Azerbaijanis, specifically de-russification of their names. I next discuss the hosting of major global events, attempts at record-setting, construction of pipelines, and development of strong national teams as examples of official movements aimed at attaining global prominence. Lastly, I consider the Azerbaijani diaspora, focusing on their activities as they related to the Khojaly tragedy. 


\subsection{Naming Patterns in Azerbaijan}

In this section, I consider Azerbaijani nationalism in relation to anti-Russian sentiments through an examination of changes in naming practices (first and last names) in Azerbaijan.

\subsubsection{Russification of First Names}

Following Azerbaijan's incorporation into the Soviet regime, it became mandatory for Azerbaijanis to register their names and to add a Russian suffix such as "-yev" or "-ov" to male names and "-yeva" or "-ova" to female names.

However, the majority of people did not have official surnames. Soviet bureaucrats often resolved this problem simply by adopting the name of the individual's father and adding traditional suffixes, such as "-yev" / "-yeva" or "-ov" / "-ova," meaning "born of." Some examples include the conversion of Ali to Aliyev (for a male) or Aliyeva (for a female), Husein to Huseinov or Huseinova, and Mammad (short for Mohammad) to Mammadov or Mammadova.

First names changed gradually during the Soviet period, influenced by the social situation and communist ideology. The general shift in naming practices that occurred during this period was primarily influenced by Russian naming practices and the communist way of life. For example, many names referred to occupations such as Traktor (tractor) and Kombayn (combine). In addition, there were names associated with the Communist Party such as Narkom (from the Russian, Narodniy Komitet, which means people's committee) and Raykom (from the Azerbaijani Rayon Komitesi, meaning regional committee). In addition, many names such as Malumat (information) were influenced by the communist regime.

During the 1920s and 1930s, new types of names became popular. Examples of male names included Azad ("freedom"), Bakhtiyar ("fortune"), Saadat ("happiness"), Ingilab ("revolution"), Mubariz ("struggle"), Mubarak and Tabrik (both meaning "best wishes"), and Vugar ("pride"), New names for females included Irada ("will" or "determination"), Matanat ("strength," "steadiness," or "tolerance"), Azade ("freedom"), and Rafiga ("friend" or "companion"), which suggested comradeship with men in building a new society. This naming pattern seems to have been intended as testimony of success or happiness associated with life in the Soviet Union.

Given the widespread use of Russian in Azerbaijan, naming patterns were also influenced by Russian customs. In 1938, when Cyrillic was imposed in Azerbaijan, Arabic had already been officially replaced by a modified Latin script, introduced in 1928. However, there was considerable confusion regarding this script. Political realities also influenced naming practices. Popular acceptance of Russian naming patterns is reflected in birth certificates issued during the Soviet period. For example, in Russian, most female names contain three syllables, with the last syllable ending with the vowel "-a." Examples include Ludmila, Svetlana, Natalya, Marina, Maria, and Tatyana. Whereas Russians stress the middle syllable in such names (e.g., lud-MI-la, svet-LA-na), in traditional Azerbaijani names, the stress is always on the last syllable of a name such as ley-LA (Leyla), sev-DA (Sevda), and re-NA (Rena). The fact that Azerbaijanis rarely adopted Russian names, outright, for their children at the beginning of the Soviet period raises the question of whether such a gesture would have overstepped Russian and/or Azerbaijani boundaries and norms. Nonetheless, Azerbaijanis gradually emulated and incorporated Russian naming patterns. Some selected names, especially for girls, derived from international stories that sounded like Russian three-syllable names such as Molière's Elmira, Zemfira (from Pushkin's Gypsies), Amalia, Ophelia, Aida, Tamilla, Tamara, and Esmira (from Esmeralda in Hugo's Hunchback of Notre Dame).

Another way of russifying traditional Azerbaijani female names was to add "-a" as a final third syllable to the original name. For example, Narmin became Narmina and Gulnar became Gulnara. The final "-a" suffix was also added to feminize traditional Azerbaijani male names (e.g., Adil-Adila, Farid-Farida, Ilham-Ilhama, Natig-Natiga, and RamizRamiza.)

Azerbaijani male names were similarly russified. The most common practice during the 1940s and 1950s was to select a fairly short Azerbaijani name consisting of two syllables. Invariably, the first syllable contained an "a" or an "o," and the second syllable contained an " $i$ " as in Rafig, Faig, Shaig, Namig, Natig, and Tofig. The final "g" in these names was often pronounced as the final " $k$ " in traditional Russian-sounding names (e.g., Vladik from Vladislav, Slavik from Svyatoslav, and Stasik from Stanislav). Many such Azerbaijani names are actually of Arabic origin, but in some cases, when transmitted via Turkish, they were pronounced and spelled with a final "k" as in Russian (e.g., Rafik, Faik, Shaik, Namik, Natik, and Tofik). The transformation, therefore, occurred naturally and was easily accepted by both communities. This pattern of imitating Russian names by substituting a final "k" is still fairly prevalent.

From the 1960s to 1990s, the practice of adopting names of foreign origin and then russifying them was very popular. Names of this type included Dinara, Diana, Elza, Elvira, Ellada, Elina, Kamilla, and Emil.

Thus, while the government did not issue any official decrees on naming, which was left to the discretion of parents, the russification of names was a natural outcome of the national Soviet policy and demonstrated the association of names with people's identities. 


\subsubsection{De-russification of First Names}

Despite its progress, a countercurrent opposed the russification process, and some people attempted to use names to express resistance.

While newly russified names were being adopted, "fresh" and "new-sounding" but decidedly Azerbaijani names appeared during the Soviet period. For example, at least 14 names were incorporated into the Azerbaijani naming system from the works of Jafar Jabbarli, Azerbaijan's first major playwright of the Soviet period. These included male names such as Oqtay ("one who stays with his tribe or people"), Yashar ("existing" or "living"), Elkhan (denoting one of the earliest Turkic ranks), Aydin ("clear"), Qorkhmaz ("fearless"), Donmaz ("not shifting" or "turning from "The Way"”) and Sonmaz ("eternally burning" or "eternally lit"). Female names derived from Jabbarli's work include Almas ("diamond"), Solmaz ("unfading" or "always fresh"), Gyultakin ("like a flower"), Sevil ("beloved"), Gyular ("smiling" or "laughing"), Gyunduz ("daytime") and Gyulush ("laughter"). These Azerbaijani names continue to be very popular.

During the late 1940s and 1950s, the renowned national poet, Samad Vurgun created names for the Moon using the Turkic root "Ay" (pronounced as "eye"). These included Aygyun ("moon-sun") and Aybeniz ("moon-faced"). Vurgun named his own daughter Aybeniz and his granddaughter, Aygyun. With the establishment of these names within Azerbaijani society, people began to create new names with the stems "Ay" (moon) and "Gyun" (sun) such as Aynur ("moonlight"), Gyunay ("sun-moon"), and Ayten ("like the moon"). Azerbaijanis continue to build upon this stem and to introduce new names, such as Aytaj ("moon-crown"), Ayshan ("moon-happy") and Aysel ("moon-rushing waters"). These names are highly popular in contemporary Azerbaijani society.

Thus, the move to de-russify names occurred naturally toward the end of the Soviet period. Some people changed their names by removing Russian suffixes and either adding traditional suffixes or omitting the suffixes altogether. They found it very difficult to change their names during the perestroika period, when this movement began because of the negative reactions of most officials. However, such name changes gradually gained acceptance.

\subsubsection{Azerbaijani Surnames}

As mentioned above, many Azerbaijanis have removed "-(y)ev", “-(y)eva”, "-ov", and "ova" from their surnames. Some have substituted traditional suffixes, such as "-zade" (of Persian origin, meaning "born of" as in Pashazade or Alizade) and "-li" / "-lu" (of Turkish origin, meaning "with" or "belonging to" as in Khanli or Koprulu), while others have omitted suffixes entirely. The choice of suffixes (none, Persian, or Turkish) constitutes one way for people to express their identities.

Name changes have also occurred in other ways. For example, in the name Narmina, the Russian-sounding final syllable "a" has been dropped, reverting the name to Narmin. An examination of 200 birth certificates issued in 19901996 revealed five occurrences of the name Narmin, while Narmina occurred only once. This is the opposite pattern to that found among 180 female names examined in the archival records for 1967-1990, wherein six records with Narmina and one with Narmin were found (Garibova \& Blair, 1996).

At the time of writing, de-russification of names has become a popular trend that is being encouraged by the government.

The Azerbaijani Terminology Commission has expressed concern regarding non-Azerbaijani sounding names. The deputy head of the Commission has even stated that Russian-sounding names like Maria Yekaterina, Olya, Alya, Sergey, Alexsandr, Dmitry, and Mikhail will be banned in the near future. She added that no Azerbaijani would want to marry someone with a Russian-sounding name. The rules would only apply to children who are ethnically Azeri. Foreigners living in Azerbaijan could still choose their children's names freely.

The Azerbaijani Terminology Commission has further stated that long names composed of two or three names such as Najafguly (Najaf and Gulu), should be banned, and that people should instead choose short, names. Under presidential decree, the Commission has already submitted name changing proposals to the Azerbaijan government.

Although outright banning of these names may not be realized, there have also been proposals to replace Russian-sounding name endings in Azerbaijani surnames, such as "-ov," "-ova," “-(y)ev" and "-(y)eva," with "-az" and "-yaz." The reason for this is that "az" denotes the Azerbaijani Internet domain.

Similarly, several new proposals have been put forward; and the Committee's proposals, which are being considered, will be accepted soon. While some Azerbaijani individuals and officials agree with the new proposal on names, others feel that any strict regulation will unfairly limit people's freedom to choose names that are already in widespread use, or that have special meanings within families. (Note 4)

Thus, while the issue of names has a bearing on nationalism, people should, as a human right, be entitled to choose names freely. Given the opposing factors at play, this problem will likely not be easily resolved. 


\subsection{International Self-Promotion: A Source of National Pride}

Following Azerbaijan's acquisition of oil and gas revenue, the country has enhanced its image through several grandiose construction projects, including buildings, towers, and pipelines, and other projects, including production of the largest national flag in the world. It has hosted various large-scale international events, and recruited top-ranking foreign athletes to promote sporting excellence. Considerable wealth, acquired from oil and natural gas resources, has made these projects possible.

Azerbaijan's self-promotion has been very effective within the country as well as internationally. This is because such tangible achievements are widely recognized, contributing to a positive image of Azerbaijan. In turn, this fosters national pride and, by extension, Azerbaijani nationalism. While it is impossible to cover all of Azerbaijan's remarkable achievements here, I will highlight some of the most impressive achievements below.

\subsubsection{The Azerbaijani Flag}

In 2011, Azerbaijan succeeded in developing the world's largest national flag, which is 70 meters long and flies atop a 162-meter flagpole. It should be noted, however, that initial record-setting attempts failed because of strong winds. (Note 5) The record was broken within a short time, and the Azerbaijani flag is currently the second largest in the world. It is on display in the newly constructed Flag Park, from where residents have been forcibly relocated, and constitutes an important land mark for Azerbaijanis.

\subsubsection{Baku's Transformation}

Baku's development is another example of Azerbaijan's attempts at self-promotion. Small buildings, houses, and roads have been demolished and several grand buildings, as well as fine, wide roads have been constructed in the city. Baku's map, including that of the old city which has been renovated, has been transformed within a decade.

The three Flame Towers, Baku's tallest skyscrapers at a height of $190 \mathrm{~m}(620 \mathrm{ft})$, have become landmarks in Azerbaijan. The buildings, comprising apartments, a hotel, and office blocks, have been built at an estimated cost of USD 350 million. Their construction began in 2007 and was completed in 2012. Dubai-based companies had a role in their design and construction. The towers aptly symbolize Azerbaijan, which means "land of fire." Their facades have been transformed into gigantic display screens deploying more than 10.000 high-power LED luminaires.

The Heydar Aliyev Center, also in Baku, is another important symbol of Azerbaijan. Heydar Aliyev, which is named after the Azerbaijani word for "charisma," is a building complex covering 619.000 square feet. (Note 6) This center was designed by Zaha Hadid, an Iraqi-British architect, known for her distinctive architecture and flowing, curved style eschewing sharp angles. (Note 7) Its construction began in 2007 and was completed in 2012.

Azerbaijan's construction boom led to the development of many kinds of buildings designed for big events, such as great halls and stadiums. The Azerbaijan government continues to host large international events in Baku.

\subsubsection{The Olympic Games}

From the 2014 Olympics onward, Azerbaijan has repeatedly bid, although unsuccessfully, to host the summer or winter Olympic Games. The National Olympic Committee of Azerbaijan was created in 1992 and was recognized by the International Olympic Committee in 1993. Azerbaijan first participated at the Olympic Games as an independent nation in 1996 and has sent its athletes to compete at all subsequent Olympic. Games.

Azerbaijani athletes have performed particularly well in combat sports, winning a total of 26 medals at the Summer Olympic Games in wrestling, shooting, boxing, judo, and weightlifting. However, no medals have been won by Azerbaijanis during the Winter Olympic Games.

In addition to strongly influencing Azerbaijani nationalism, the Games have had political effects. For example, former President, Haydar Aliyev, appointed his son, Ilham Aliyev, as the president of the National Olympic Committee of Azerbaijan, despite the fact that holders of this post have normally been elected. He has retained the post since 1997 until the time of this writing, and he was re-elected in 2001, 2008, and 2011. (Note 8) Ilham Aliyev was in fact disliked by Azerbaijanis during Heydar Aliyev's lifetime. However his reputation improved after the 2000 Olympics, during which Azerbaijan won three medals, including two gold ones. (Note 9) As the president of the National Olympic Committee of Azerbaijan, Ilham Aliyev attended all of the Olympic events. The Olympics have strongly influenced Azerbaijani nationalism, with attempts to host big games in Azerbaijan and receiving as many medals as possible being key aspects of this nationalism. It is important to stress here that, as previously mentioned, despite criticism of their authoritarian rule, the Aliyev family is highly respected in Azerbaijan.

At the time of writing, while Azerbaijan has not succeeded in hosting any Olympic Games it has hosted some other international sporting events, for example, in the fields of soccer and judo. The largest of these events was the European Games held in Baku in June 12-28, 2015. This was a significant event, regarded as a small-scale version of the Olympic 
Games. In addition, the inception of the European Games took place in Azerbaijan, which won the most medals after Russia. (Note 10) Moreover, it has been decided that the 2016 Formula 1 Grand Prix of Europe will be held in Baku the Baku City Circuit, the construction of which is set to be completed before June 2016.

To win more medals in such international games, Azerbaijan has recruited a number of foreign athletes, a common practice among nations, including Canada, Russia, and the US, has become widespread (Wilson \& Lehren, 2008). (Note 11)

Some individuals, facing citizenship processing delays in their home countries, applied for fast-track Azerbaijani citizenship to enable them to represent the country at skating events during the 2010 Winter Olympic Games held in Vancouver, Canada. For example, Morgan Matthews followed in the footsteps of the American-born ice dancer, Kristin Fraser, who represented Azerbaijan during the 2006 Olympics without ever having visited the country.

At the 2012 Olympics, held in London, UK, where more than 50 athletes represented Azerbaijan, almost half were naturalized citizens originating from foreign countries. This highlighted a serious issue, which was further confirmed by an event in 2011, where two teenaged Bulgarian weightlifters, Boyanka Kostova and Valentin Hristov, switched their allegiance to Azerbaijan after Baku agreed to pay Bulgaria more than $\$ 500000$ to procure talented athletes. However, Bulgaria demanded an additional fee when it became clear that the duo would represent Azerbaijan at the 2012 Olympics, arguing that the original agreement did not permit this and threatening to block their participation. After months of squabbling, Bulgaria eventually relented and agreed to allow Kostova and Valentin to lift weights for Azerbaijan in London (Bigg, 2012; Kozlowska \& Traywick, 2014).

In addition, the inclusion of no less than six South Korean players in the women's field hockey team representing Azerbaijan at the European Championship caused outrage (Slot, 2008). Evidently, Azerbaijan has used large sums of money to attract top athletes to maximize wins in international games, and consequently to strengthen national pride.

\subsubsection{The Eurovision Song Contest}

The various new extravagant buildings in Azerbaijan include a grand music hall. Within the wider community of European nations participating in the annual Eurovision Song Contest, the nation to which the winner belongs hosts the Contest the following year. Azerbaijan made its debut at the Eurovision Song Contest in 2008, and its pop duo, Eldar and Nigar (also known as Ell and Nikki) won the contest in 2011. This brought great honor to the Azerbaijanis and to Azerbaijan, which gained the right to host the Eurovision Song Contest in 2012. In preparation for hosting the 2012 Contest, Azerbaijan constructed a magnificent hall and related buildings; this involved extensive forced migrations in the construction zone. It is not widely known that many protest movements were initiated to oppose the construction.

Moreover, substantial corruption relating to the construction was uncovered. In May 2012, a joint investigation was launched by Radio Free Europe/Radio Liberty and the Organized Crime and Corruption Reporting Project. A leading Azerbaijani journalist, Khadija Ismayilova, discovered that the Aliyev family had personally profited from the construction of the Crystal Hall, the new concert showplace built to host the 2012 Eurovision Song Contest at a cost of USD 134 million. (Note 12) Thus, while being a potent symbol of Azerbaijani national pride and nationalism, it also brought considerable disgrace to Azerbaijanis.

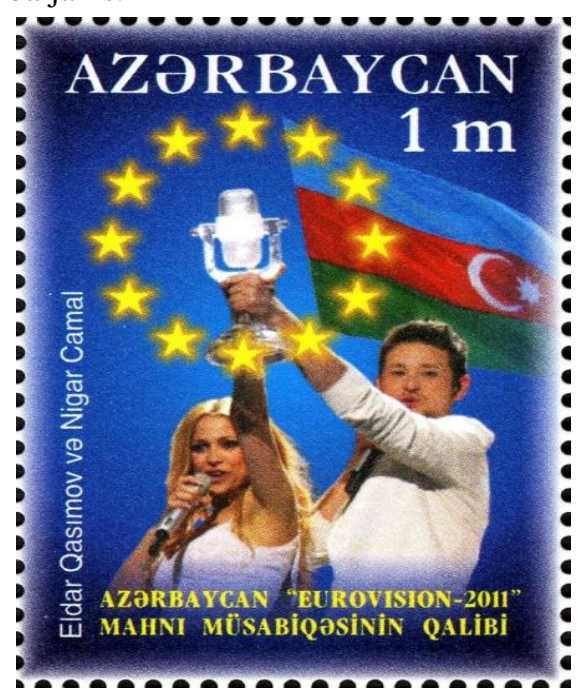

Figure 1. The 2011 Azerbaijani commemorative stamp

Description: This stamp portrays Eldar's and Nigar's winning of the 2011 Eurovision Song Contest. 


\subsubsection{Oil and Gas Pipelines and Communication Networks}

Azerbaijan is making good use of its resource wealth to position itself as a regional hub for oil and natural gas as well as rail and road networks linking Azerbaijan, Georgia, and Turkey with Europe. In 2006, the well-known Baku-Tbilisi-Ceyhan (BTC) oil pipeline began operations, serving as the main pipeline for exporting Azerbaijani gas. Moreover, it is also a political pipeline. Within Azerbaijan, the BTC pipeline is known as the "Heydar Aliyev" pipeline in honor of the national hero. The Baku-Tbilisi-Erzurum Gas pipeline has also been constructed, running alongside this pipeline. Azerbaijan, Georgia, and Turkey are now working to develop a rail and road network connecting Baku with Tbilisi and Kars. After the collapse of the plan to develop the Nabucco pipeline as the new southern pipeline extending from Azerbaijan to Europe, detouring Ukraine, it was decided that three relatively small and connected pipelines would be constructed instead. These are: the Nabucco-West pipeline, the Trans Adriatic Pipeline, and the Trans Anatolian Natural Gas Pipeline. While both Azerbaijan and Turkey are responsible for the latter, this can be considered an Azerbaijani project, because the operator is the State Oil Company of the Azerbaijan Republic (SOCAR) which holds a $58 \%$ share in this project. (Note 13) Such international infrastructure is also fostering Azerbaijani national pride and has raised Azerbaijan's status globally.

\subsubsection{The Role of the Azerbaijani Diaspora in Promoting Nationalism: Focusing on the Khojaly Tragedy}

The impact of the NKC on Azerbaijani nationalism seems to be waning every year, with more than two decades having passed since the declaration of a ceasefire. However, as a key symbolic reminder of the NKC, the Khojaly tragedy continues to fuel Azerbaijani nationalism.

The Khojaly tragedy, also known as the Khojaly Massacre, refers to a serious incident that occurred during the NKC on February 25-26, 1992. According to the Azerbaijani government, as well as Memorial Human Rights Center, Human Rights Watch, and other international observers, the massacre was committed by ethnic Armenian armed forces, reportedly with the help of the Russian $366^{\text {th }}$ Motor Rifle Regiment, which did not apparently act on orders from the command. The death toll claimed by Azerbaijani authorities was 613 civilians, including 106 women and 63 children. This incident was the worst and largest massacre that occurred during the conflict and became symbolic of the NKC, further fueling Azerbaijanis' feelings of enmity toward the Armenians. The conflict has inspired numerous mourning ceremonies and events, worldwide.

Within Azerbaijan, many such ceremonies and events are held, and TV programs about the conflict are broadcasted every year. In recent years, the Azerbaijani diaspora has organized such events worldwide, especially in the US.

The term "diaspora" initially referred to the dispersal of the Jews outside of Palestine after Babylon's capture. However, it now refers more broadly to any group dispersed, for whatever reason, outside of its traditional homeland.

The Azerbaijani diaspora is not insignificant in size and its influence is growing. It comprises Azerbaijani communities living outside of Azerbaijan or within the Iranian portion of Azerbaijan. Its numbers and distribution are shown in Table 1.

The State Committee of the Azerbaijan Republic on Work with Diaspora was specifically established to handle communications with the diaspora and to promote the creation of new societies and organizations. By 2004, the Committee had succeeded in creating about 40 new Azerbaijani communities worldwide. (Note 14) Of these, Azerbaijani societies or organizations in the US, Russia, and Germany have been especially prominent, with many Azerbaijani communities in these countries being very active. (Note 15)

Table 1. The Azerbaijani diaspora

\begin{tabular}{|c|c|c|c|}
\hline & Country & Registered Azerbaijani Population & Estimated Azerbaijani population \\
\hline 1 & Russia & $603070(2010)$ & $1500000-3000000$ \\
\hline 2 & Turkey & ------ & 800000 \\
\hline 3 & Georgia & 284761 (2002) & $360000(2007)$ \\
\hline 4 & Kazakhstan & $85292(2009)$ & 150000 \\
\hline 5 & Germany & $15219(2006)$ & 200000 \\
\hline 6 & Ukraine & $45176(2001)$ & ------ \\
\hline 7 & Netherlands & ------ & $7000-18000(2009)$ \\
\hline 8 & Kyrgyzstan & 17267 (2009) & ------ \\
\hline 9 & United Kingdom & ------ & $15000(2009)$ \\
\hline 10 & United States & $\begin{array}{l}14205 \text { (2000)(from the Republic of } \\
\text { Azerbaijan) } \\
40400 \text { (from Iran) }\end{array}$ & 400000 \\
\hline
\end{tabular}




\begin{tabular}{|llll|}
\hline $\mathbf{1 1}$ & Canada & $4580(2011)$ & 80000 \\
\hline $\mathbf{1 2}$ & France & ----- & 70000 \\
& & 1112 (asylum-seekers) \\
\hline $\mathbf{1 3}$ & Uzbekistan & $44410(1989)$ & ------ \\
\hline $\mathbf{1 4}$ & Turkmenistan & $33365(1989)$ & ----- \\
\hline $\mathbf{1 5}$ & Belarus & $5567(2009)$ & ----- \\
\hline $\mathbf{1 6}$ & Latvia & $1697(2001)$ & ----- \\
\hline $\mathbf{1 7}$ & Estonia & $880(2000)$ & ------ \\
\hline $\mathbf{1 8}$ & Lithuania & 788 & ----- \\
\hline $\mathbf{1 9}$ & Tajikistan & $800(2000)$ & ----- \\
\hline $\mathbf{2 0}$ & Australia & 300 & ----- \\
\hline $\mathbf{2 1}$ & Austria & 1.159 & ----- \\
\hline $\mathbf{2 2}$ & Denmark & 231 & ------ \\
\hline
\end{tabular}

Description: The table depicts the registered and estimated populations of a number of countries.

Examples of such activities include actions to promote memorials relating to the Khojaly tragedy. This paper focuses on movements in Washington, DC, and New York, where memorials have been organized annually since 2010 with the cooperation of the Azerbaijani government and Azerbaijani diasporic organizations. Their aim is not only to sustain the memory of the Khojaly tragedy, but also to foster wider recognition of this event abroad, especially in influential global centers such as Washington, DC, and New York.

The Azerbaijani-American Alliance (AAA), which was founded as a non-partisan and non-profit organization, and has been active in the US, conducts large-scale campaigns focusing on the Khojaly tragedy.

According to the AAA, as part of this campaign, hundreds of ads bearing the slogan "Khojaly: A Human Tragedy Against Azerbaijan" (see Figure 2) were posted on portable and stationary information boards at metro stations, bus stops, and on the exteriors of buses and trains. They were even posted in conspicuous areas in the two cities such as the large board in New York's Times Square. These informative signs, posted on the sides of buildings, are illuminated by the lights of passing cars. At some locations, several video posters rotating at 180 degrees have also been installed.

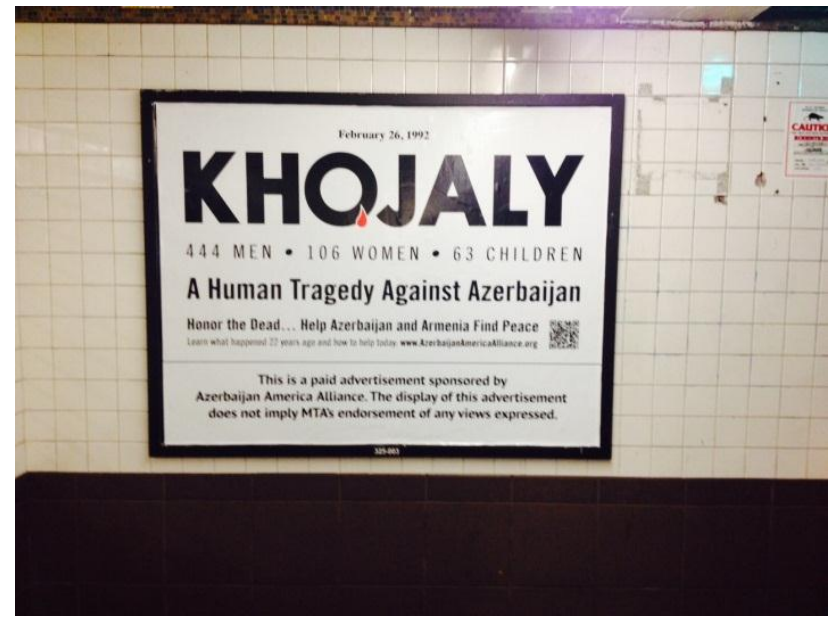

Figure 2. A commemorative sign about the Khojali tragedy posted by the Azerbaijani diaspora in New York Description: The photograph was taken by the author on January 11, 2014 at a New York metro station.

Members of the Azerbaijani diaspora believe that, through their activities, millions of Americans will become aware of the Khojali tragedy. It is their aim, and that of the Azerbaijani government, to foster wider recognition of the tragedy and of the harshness of the Armenians.

Some groups have also initiated protests. For example, the Azerbaijan Association of New York organized a demonstration in front of the Armenian Mission to UN and the UN building located at the corner of Dag Hammarskjold Plaza on February 26, 2015.

In addition to public awareness efforts, the Khojaly campaign has included lobbying efforts aimed at convincing legislative bodies at various levels to formally recognize the massacre. In 2013, a petition seeking formal recognition of the tragedy was submitted to the White House. Thus far, state legislatures in Arkansas and New Mexico have adopted 
resolutions commemorating Khojaly. Since 2010, legislatures in Massachusetts, Texas, New Jersey, Maine, and Georgia have also recognized Khojaly, with another "two to three" states working on this, according to Adil Baguirov, the co-founder and managing director of the US Azeris Network (Baguirov, 2013). In addition, national parliaments in Mexico, Colombia, Pakistan, and the Czech Republic have formally recognized the Massacre.

However, the campaign has not always proceeded smoothly. For example, a petition calling on the White House to "issue a proclamation commemorating and recognizing the war crime of the Khojaly massacre, and its victims" (Kucera, 2013) received more than 125000 signatures in 2013. It was the second most popular petition in the short history of the White House's public petition program, under which the presidential administration will respond to any petition with more than 100000 signatures. However the official White House response was tepid: "While we will not be issuing a Presidential Proclamation, the United States deeply regrets the tragic losses of life in the war between Azerbaijan and Armenia" (Kucera, 2013). Although very disappointed, Azerbaijanis have affirmed that they will continue their activities with enthusiasm. (Note 16)

\section{The Regional and International Contexts}

\subsection{Has Nationalism Influenced the Iranian Azerbaijanis?}

The Aras River divides the Azerbaijanis into those living in Azerbaijan and those in Iranian territory. It is not known exactly how many Azerbaijanis live in Iran. However, this population is estimated to be more than double that that of the Azerbaijan Republic. The reason for the division of Azerbaijanis within two states originates from the Treaty of Turkmenchay (1828), wherein Iran was forced to cede its dependent khanates located north of the Aras River to Russia. Consequently, Azerbaijanis refer to the Azerbaijan Republic as "North Azerbaijan" and to northern parts of Iran inhabited by Azerbaijani as "South Azerbaijan." Although both groups speak Azeri and share the same culture, their intonations differ slightly and their perceptions and ways of thinking are also different. However, many Northern Azerbaijanis tend not to differentiate between Azerbaijanis living in the Republic and in Iranian Azerbaijan, regarding the latter as "kith and kin and not small people have family [on] the other side of the River Aras (Atabaki, 2000; Fawcett, 2009; Heradstveit, 2009).

Within the multiethnic Iranian state, the Azerbaijanis constitute the largest minority group, variously estimated to comprise between a fifth and a third of the total population. Many Azerbaijanis also have highly influential positions within Iran, especially in business, social and religious circles. For example, Ali Hosseini Khamenei, the second and current Supreme Leader of Iran and a Muslim cleric, is ethnically Azerbaijani. Furthermore, the warm climate and fertile land of northern Iran, where the Azerbaijani reside, are well suited to agriculture. Consequently, Iran highly values this area and its people and aims to retain them.

While Azerbaijanis, especially the nationalists and intelligentsia, in the Azerbaijan Republic have long attempted to recover "South Azerbaijan," there has been no large-scale movement for integration except for a very short time during perestroika. However, most of the Iranian Azerbaijani have never wanted integration with the Azerbaijan Republic. When I interviewed them, they provided the following reasons. (Note 18) They accord the highest value to stability and Iran provides them with such stability, enabling them to live without any shortages relating to jobs, foods, and money. Conversely, the Azerbaijan Republic is in conflict with Armenia and has been confused by issues relating to Russia. However, the Azerbaijani language is not officially used in Iran, including in schools, and alcohol consumption is banned. These are causes of dissatisfaction among Iranian Azerbaijanis. (Note 19) The Iranian Azerbaijanis, like many people in the former USSR, seem to be yearning for stability more than freedom. In addition, the rights of Iranian Azerbaijanis seem to be improving. For example, in 1997, the policies of President Muhammad Khatami, then newly elected, widened the scope of cultural rights for minorities to win the support of the periphery.

However, Iran has been overly apprehensive about movements to integrate Azerbaijanis across Azerbaijan and Iran, although such movements may not occur in the near future and most Iranian Azerbaijanis want to maintain the status quo. Iranian authorities also fear that the Azerbaijan Republic, as a large, rich, successful, and attractive country, will be very appealing to Iranian Azerbaijanis who may desire integration with Azerbaijan. Therefore, Iran has a negative attitude toward Azerbaijan and is trying to undermine the Azerbaijan Republic. This is reflected in Iran's support for Armenia, a Christian state, during the NKC and its attempts to obstruct Azerbaijan's oil and gas projects, despite the fact that both Azerbaijan and Iran are Islamic (Shi' 'ite) states. (Note 20)

Currently, however, Azerbaijan is acknowledged as an economically successful state because of its oil and natural gas wealth, and Azerbaijani nationalism is growing.

\subsection{Recent Activities and Movements of Iranian Azerbaijanis}

While there were only a few movements focusing on the integration of the Azerbaijanis at the end of the perestroika period, pan-Azerbaijani movements have emerged over the last decade. 
Nationalism is often triggered by tragedies, including war, conflict, political turmoil, and natural disasters. Although Azerbaijani nationalism has always existed in northwestern Iran, it has greatly increased from the 1990s onward. This can be attributed to a combination of several different factors affecting the Azerbaijani minority. Here, I identify the most important factors that have influenced Iran's Azerbaijanis.

An immanent American attack on Iran in the spring of 2006 prompted a revival of the flagging idea of a pan-Azeri identity. Indeed, Azerbaijan feared that a military attack on Iran could destabilize the country to such a degree that oppressed minorities could seek new alliances with surrounding states and ethnic groups.

Subsequently, riots broke out in May and June of 2006. On May 12, 2006, the Iranian state newspaper, Iran, printed a grossly insulting caricature of an Azerbaijani as a stupid, dirty cockroach with an article directed against the Azerbaijani minority. Following this publication, thousands of demonstrators amassed in cities of Iran that were mostly populated by Azerbaijanis, as well as in Tehran, where demonstrations were initiated by students. The protestors even seized a television transmitter for a short period in the western city of Urmia, as well as a municipal building in the eastern city of Sulduz. The vast majority of local police and militia groups, composed of ethnic Azerbaijanis, refused to take action against their compatriots. The demonstrators called for punishment of those responsible for the caricature and the article; a demand that was finally met. The authors of the article and the editor-in-chief of the newspaper were dismissed, and publication of the newspaper was temporarily suspended. However, the demonstrations continued. Protestors shouted political slogans such as: "I am proud to be a Turk!" "Down with Persian chauvinism!" "Keep your hands off of Azerbaijan!" and "We want instruction in Turkish in our schools!" Militia and army units were called in from other areas in Iran to end the demonstrations, resulting in dozens of deaths. According to some reports, mainly provided by Azerbaijani nationalists, there were more than 100 victims. The exact number of victims is not, however, known because of Teheran's strict information embargo concerning the events in northwestern Iran (Alikhan, 2008, p. 98). Thus, if a conflict or a domestic crisis were to occur, it would likely fuel Azeri ethno-nationalism.

Further, a sizeable number of young Iranians are dissatisfied with the restrictive regime of the clerics, and this dissatisfaction was exacerbated during the bloody unrest surrounding the reelection of Mahmoud Ahmadinejad in 2009. At that time, feelings against the Iranian authorities had some impact on assertions of Azerbaijani nationalism and other (Moosavi, 2007).

Technical developments too have helped to strengthen self-identification among Iranian Azerbaijanis. For many years, Iranian Azerbaijanis could only watch the news on Azerbaijani television channels, and that too, for just 30 minutes in a week. However, by accessing satellite broadcasts, they are not only able to watch Azerbaijani channels now, but also Turkish and western channels (Souleimanov, Pikal, \& Kraus, 2013). Such programs have enhanced feelings of being "Azerbaijani” or "Turkish" among Iranian Azerbaijanis.

Commencing from 2000, the Lake Urmia controversy has led to infusion of the environmental movement with Azerbaijani nationalism. Located on the border between the Iranian provinces of Western and Eastern Azerbaijan, Lake Urmia is a unique natural site and is listed as a UNESCO biosphere reservation. However, this salt lake faces severe environmental threats attributed to its lack of outflow and agricultural intensification in surrounding areas. Moreover, increasing use of water from rivers that feed the lake and the construction of over 30 dams in these streams have led to steady shrinkage of the lake's surface area. According to some experts, the lake could dry up completely within just a few years. However, the Iranian government has not taken any serious measures to address this issue. Iranian Azerbaijanis, for whom the lake is symbolic of Southern Azerbaijan, feel strongly about this and have launched a series of protests, hoping to draw attention to this serious ecological problem. The Iranian authorities took a very hard line against the demonstrators, as they always do. Consequently, the demonstrators reacted by raising political and nationalistic issues during the protests.

Despite the government's negative reaction, further demonstrations occurred in mid-2011, during which slogans such as: "Lake Urmia is drying up; Iran has ordered its execution," and "Urmia is thirsty. Azerbaijan must take a stand or lose the lake" were common (Souleimanov, Pikal, \& Kraus, 2013).

Thus, while the Iranian Azerbaijani undertook several nationalistic actions or demonstrations, the Iranian government's consistently negative attitude and harsh responses repeatedly reinforced Azerbaijani nationalism, resulting in a vicious cycle.

From the early 2000s, in spite of restrictions imposed by the Iranian authorities, Azerbaijanis have held regular mass marches to their nationally symbolic sites: Mount Savalan and the Bazz Fortress. Separatist slogans, pan-Turkic symbolism, and displays of the banned flag of South Azerbaijan (which is similar to that of the Republic of Azerbaijan) are widely deployed during these marches. In addition to the marches, clashes between ethnically Azerbaijani and Persian soccer fans are becoming increasingly frequent. Moreover, anonymous posters calling for instruction in Turkish, along with flags of Azerbaijan and Turkey, have begun to appear in Tabriz, Urmia, Maraz, Sulduz, Ardabil, and several other 
towns in Iranian Azerbaijan. The posters are put up overnight in prominent places and are immediately torn down by police and militia units.

In addition, some explosions occurred at the police station in northern Iran in 2009, for which Azerbaijani nationalists were thought to be responsible. Azerbaijani nationalistic movements have been limited up to now in Iran. However, authorities in both Azerbaijan and Iran fear that the movements could connect nationalists residing in Azerbaijan and Iran and, therefore, expand.

\subsection{Keeping the Balance: The Role of Diplomacy}

In recent years, there have been dramatic changes in the global situation, notable examples being the Ukrainian and Syria crises. These developments have created a difficult situation in and around Russia, which is a very important neighbor to Azerbaijan. In addition, China's global influence has radically increased, as evidenced by its efforts to realize its goal of "One Belt, One Road" and its leading role in founding the Asian Infrastructure Investment Bank (AIIB).

However, Azerbaijan does not seem to have been significantly affected by these radical changes in the international environment. From the time of Heydar Aliyev's presidency and the establishment of the "Aliyev regime," Azerbaijan has maintained a good balance, diplomatically, between Russia and the West (the US and Europe). The Azerbaijanis strongly support this diplomatic policy because of the difficulties they experienced during the time of the Elchbei regime, which, as previously mentioned, invited reprisals from Russia because of its strongly pro-West and pro-Turkey stance.

Georgia, Azerbaijan's neighbor, has adopted an anti-Russian and pro-Western policy, inviting many kinds of retaliatory actions by Russia such as economic sanctions, the August War in 2008, and recognition of the independence of Abkhazia and South Ossetia, which are not recognized by Georgia. Azerbaijan's careful efforts to maintain a balance between Russia and the West seem to have been successful. (Note 21) Despite its close relations with Turkey, Azerbaijan was able to maintain a status quo with both Turkey and Russia after their relationship was seriously undermined by an incident entailing the shooting down of a Russian military airplane by Turkey in November 2015 . Consequently, Russia has not taken a strong stance against Azerbaijan in recent years and the relation between them is stable.

Moreover, Azerbaijan has not been affected by the situation relating to Iran, for example, the lifting of sanctions against Iran by the West especially by the US. Despite being close neighbors, the two countries have a strained relation.

A final point is that Azerbaijan has not been affected by recent Chinese activities. China, which has been extending its influence in Eurasia, including the former USSR, through its "One Belt, One Road" policy, maintains that it has already established strong ties with Azerbaijan. This is evidenced, according to China's leaders and media, by goods that Chinese have transported via rail, although in fact they not only used the rail transportation to Turkmenistan, but also transportation by vessel across the Caspian Sea from Turkmenistan to Azerbaijan. In addition, Azerbaijan has joined the AIIB, which is mainly led by China. Azerbaijan's neighbor, Georgia, has been strongly influenced by China, with many Chinese companies operating in Georgia. However, Azerbaijani officials, journalists, and academicians deny China's claims of an association with Azerbaijan, claiming that Azerbaijan is still free from Chinese influence and that there has not yet been any significant movement of Chinese companies into Azerbaijan (Note 22).

Thus, Azerbaijan has been successful in maintaining a balanced policy and self-reliance. Moreover, a factor that seems to have fueled Azerbaijani nationalism is such strong attitudes on the part of other sovereign states.

\section{Conclusion}

This paper has attempted to elucidate the complex situation of Azerbaijani nationalism. Despite its brief history, Azerbaijani nationalism has been complicated, entailing a shift in its characteristics over a short duration commencing from its second independence after 1991.

Azerbaijani nationalism has been influenced by many factors, including religion, history, culture and relations with Iranian Azerbaijanis. While the NKC and relations with Russia prompted nationalism among the Azerbaijanis, its characteristics changed, over time, after the NKC ceasefire.

Movements around nationalism, in addition to domestic practices such as name changes, have been important factors behind recent trends in Azerbaijani nationalism. Efforts to appeal to the international community through various constructions and good performances at international competitions, and by hosting large-scale events, have had significant effects on Azerbaijanis as well as on the international community. In addition, the activities of the Azerbaijani diaspora, supported by the Azerbaijan government, are also attracting attention. Movements relating to Azerbaijan nationalism further resonate with those of Iranian Azerbaijanis. Especially in recent years, Azerbaijani 
nationalism within Iran has been growing, prompted by the situation of the Azerbaijan Republic, political and economic dissatisfaction with the Iranian government, and free access to global information. In addition, the Aliyev regime has succeeded in maintaining balanced diplomacy not only between Russia and the West, but also between Russia and China, along with a policy of self-reliance.

Thus, while Azerbaijani nationalism has been considered an outcome of the NKC, it has subsequently been transformed and is now multilayered and complex. Thus, whereas Azerbaijani nationalism has been attributed solely to anti-Armenian and anti-Russian sentiments, national pride which has been fueled by domestic and international factors, is currently playing an important role in its creation and maintenance.

However, recent expressions of Azerbaijani nationalism have been extravagant and are sustained by Azerbaijan's economic prosperity, based on its oil and gas wealth. The present base of nationalism is thus weak and fragile, and Azerbaijan should, consequently, change its underlying attitude relating to its nationalism policy. The Azerbaijani government should diversify its economy and growth, maintaining Azerbaijani nationalism, domestically and internationally, at a much lower cost.

\section{Acknowledgments}

This paper was presented at the ICCEES IX World Congress 2015, held in Makuhari, Japan in August 2015. I appreciate the important comments of my panel colleagues and the audience. I also thank Mr. Viacheslav Aldzhanov, who provided valuable information on Azerbaijani names.

\section{References}

Alikhan, F. (2008). The politics of satellite television in Iran. In M. Semati (Ed.), Media, culture and society in Iran. New York: Routledge.

Atabaki, T. (2000). Azerbaijan: Ethnicity and the struggle for power in Iran ( $2^{\text {nd }}$ ed.). London: I. B. Tauris \& Co. Ltd.

Baguirov, A. (2013, February 21). "Khojaly Massacre deserves recognition," Congress Blog.

Bigg, C. (2012, July 15). Athletes switching nationalities in spotlight at London Olympics. Radio Free Europe/Radio Liberty. Retrieved July 27, 2015 from http://www.rferl.org/content/athletes-switching-nationalities-in-spotlight-at-london-olympics/24645792.html.

Bolukbasi, S. (2011). Azerbaijan: A political history. London: I. B. Tauris \& Co. Ltd.

Demirtepe, T., \& Laciner, S. (2004, November 23). The role of the Karabakh issue in restoration of Azerbaijani nationalism. The Journal of Turkish Weekly. Retrieved July 24, 2015 from http://www.turkishweekly.net/2004/11/23/article/the-role-of-the-karabakh-issue-in-restoration-of-azerbaijani-natio nalism.

Fawcett, L. L. (2009). Iran and the Cold War: The Azerbaijan crisis of 1946. Cambridge: Cambridge University Press.

Garibli, E. (1999). What's in a name? Nationality for starters. Azerbaijan International, 7(3), 47, Autumn.

Garibova, J., \& Blair, B. (1996). Names. History in a nutshell: $20^{\text {th }}$ century personal naming practices in Azerbaijan. Azerbaijan International, 4(3).

Heradstveit, D. (2009, January 29). Azerbaijani Ethno-nationalism: A danger signal for Iran. Washington D.C.: The Middle East Institute. Retrieved July 25, 2015 from http://www.mei.edu/content/azerbaijani-ethno-nationalism-danger-signal-iran

Hirose, Y. (2006). Aspects of genocide in Azerbaijan. Comparative Genocide Studies, 2, 32-44, 2006

Hirose, Y. (2007). Visions for mountainous Karabakh: From the Azerbaijanis and the Armenians. In S. Lidell (Ed.) International visions: The Armenia-Azerbaijan conflict over Karabakh from history to future peace prospects Azerbaijan: Visions of Azerbaijan, 117-136.

Hirose, Y. (2014). The need for standard policies on state recognition: The case of the Russia-Georgia War, Georgia, and Azerbaijan from 2008 to early 2012. International Relations and Diplomacy 2(1), 1-15. http://dx.doi.org/10.17265/2328-2134/2014.01.001

Kozlowska, H., \& Traywick, C. A. (2014, June 2). In the Olympics, the country you represent could be meaningless. The News-Herald. Retrieved July 27, 2015 from

http://www.news-herald.com/sports/20140206/in-the-olympics-the-country-you-represent-could-be-meaningless.

Kucera, J. (2013, March 1). Azerbaijan: Baku Presses Campaign for Khojaly Recognition. Eurasianet. Retrieved July 25. http://www.eurasianet.org/node/66628. 
Moosavi, N. (2007), Secularism in Iran. In B. A. Kosmin \& A. Keysar (Eds.) Secularism and secularity: Contemporary international perspectives, Hartford: Institute for the Study of Secularism in Society and Culture), 143-145.

Ohannes, G. (2012). Ethnicity, nationalism and conflict in the South Caucasus: Nagorno-Karabakh and the legacy of Soviet Nationalities Policy. Farnham, UK: Ashgate Publishing Ltd.

Slot, O. (2008, April 10). Buying the flag: Kenyans are exploited like 'slaves' in talent trade. Times (London). Retrieved July 27, 2015 from http://www.timesonline.co.uk/tol/sport/more_sport/athletics/article3716012.ece.

Souleimanov, E., Pikal, K., \& Kraus, J. (2013). The rise of nationalism among Iranian Azerbaijanis: A step towards Iran's disintegration? Middle East Review of International Affairs, 17(1), 71-91.

http://www.rubincenter.org/2013/03/the-rise-of-nationalism-among-iranian-azerbaijanis-a-step-toward-irans-disinte gration/.

Wilson, D., \& Lehren, A. W. (2008, June 15). Swapping passports in pursuit of Olympic medals. New York Times. Retrieved from http://www.nytimes.com/2008/06/15/sports/olympics/15citizen.html?_r=0.

\section{Notes}

Note 1. These findings are based on the author's interviews with Azerbaijanis from 2000 to 2013. However, they only apply to people older than 40 years old.

Note 2. The Nagorno-Karabakh conflict between the Republic of the Armenian Republic and Azerbaijan centered on the self-declared Nagorno-Karabakh Republic, which was formerly an autonomous region of Azerbaijan. Ethnic Armenians living in this region periodically initiated movements calling for annexation to Armenia during the Soviet period. In light of perestroika, ethnic Armenians launched a new and initially peaceful movement in the late 1980s. However, following the Sumgait Incident in February 1988, standpoints changed. While Armenians have insisted that the incident constituted genocide against their people, the Azerbaijanis claim that it was an Armenian conspiracy. The movement subsequently became violent and both sides initiated radical actions such as ethnic cleansing. After the collapse of the USSR in 1991, the conflict escalated into a war between Azerbaijan and Armenia, with Russia supporting Armenia, which, therefore, had an advantage. In 1994, an official ceasefire was signed with Russian mediation, and Nagorno Karabakh's status as the "Nagorno Karabakh Republic" has remained unrecognized. The ceasefire was been almost kept after 1994, although there were some armed crashes and not small soldiers and residences of both sides were killed or wounded every year. However, the tensions between Armenian and Azerbaijani armed forces along the line of contact (LOC) escalated and it caused a five-day exchange of fire from 2nd April 2016, which was the biggest and bloodiest military confrontation since the 1994 ceasefire agreement. The ceasefire agreement is almost kept as of $8^{\text {th }}$ April 2016, however it is impossible to predict whether or not ceasefire will continue into the future.

Note 3. "Black January" (Azerbaijani: Qara Yanvar) was a violent crackdown by the Soviet army that took place on January 19-20, 1990 in Baku. Following the incident, USSR President Gorbachev and Defence Minister Yazov asserted that military law was necessary to halt the violence committed against the Armenian population and to thwart the efforts of the Azerbaijani independence movement to overthrow the Soviet-backed Azerbaijani government. However, Yazov acknowledged that the real purpose of "Black January" was to dismantle the Azerbajani Popular Front, which was very active and effective at that time. In 1995, Gorbachev apologized, admitting that the operation had been a grave error. After "Black January," the APF lost power and the Communist Party regained its position. According to official estimates, between 133 and 137 Azerbaijani civilians died, 800 people were injured, and 5 persons went missing. However unofficial number put the number of victims who died at 300 .

Note 4. See: Azerbaijan 'may ban Russian names,'_BBC News, March 5, 2013.

http://www.bbc.com/news/world-europe-21658746

Note 5. Baku means" the city of wind."

Note 6. For more details on the Heydar Aliyev Center, see: http://www.heydaraliyevcenter.az/\#main.

Note 7. Zaha Hadid is widely known as the "queen of the unbuilt" because the complexity of her designs makes them highly expensive. Consequently the Japanese government rejected her design submitted for the main stadium to be used for 2020 Olympics. We can, therefore, conjecture on how huge a sum of money the Azerbaijani government paid her for designing this center. Hadid has also been criticized by the Western media and by humanitarian organizations, because some people feel that the selection of her design implies her cooperation in maintaining Azerbaijani authoritarianism.

Note 8. The National Olympic Committee of the Azerbaijani Republic. For further details, see: http://www.acnolympic.org/nocs/nocs-directory/europe/azerbaijan/ 
Note 9 See the National Olympic Committee Homepage on Azerbaijan (http://www.olympic.org/azerbaijan).

Note 10. Further details can be found at the official site of the European Games:

http://www.baku2015.com/news/index.html.

Note 11. For example, out of 3000 athletes who competed at the 2014 Winter Olympics held in Sochi, 120 participated in teams that did not represent their birth countries. Numbers of such athletes were highest for the following countries: Canada: 9, Russia: 7, United States: 7, France: 6, Australia: 5, Germany: 5, Israel: 5, Italy: 5, Azerbaijan: 4, Belarus: 4, and Ireland: 4. (http://www.ksl.com/?nid=335\&sid=28799121).

Note 12. Khadija Ismayilova is a highly capable journalist who has won prestigious international journalism awards. She was arrested based on a trumped-up charge and placed in a cell before the trial. She is currently undergoing an unfair trial.

Note 13. SOCAR initially retained $80 \%$ of the shares, while two Turkish companies (BotaŞ and TPAO) held the remaining 20\%. However, BP subsequently joined this project. Consequently, the division of shares is now $58 \%$, $30 \%$, and $12 \%$ held by SOCAR, BotaŞ, and BP, respectively.

Note 14. See the Azerbaijani Government's official website:

http://www.azerbaijan.az/portal/Society/Diaspora/diaspora_01_e.html.

Note 15. Based on the author's interviews conducted in Russia in 2005, in Germany in 2010, and in the US in 2013.

Note 16. Based on the author's interviews conducted in New York in 2013.

Note 17. Iranian Azerbaijanis interviewed by the author in Tabriz in East Azerbaijan Province from August 23-30, 2005 included academicians, religious officials, students, and general citizens.

Note 18. According to Islamic rules, Muslims are not permitted to drink alcohol. However, Muslims in the Azerbaijan Republic follow these rules very loosely. Therefore, many drink alcohol, ignore Ramadan, and (women) do not wear scarves.

Note 19. Actually, Muslim cannot drink alcohols by the Islamic rule, however the Muslims of Azerbaijan Republic are very loose for the Islamic rule. Therefore many of them are drinking alcohols, ignoring Ramadan, and not wearing scarf and so on.

Note 20. For further details, see Hirose (2014).

Note 21. Based on the author's interviews held in Baku in November 2015.

\section{$(\mathrm{cc}) \mathrm{BY}$}

This work is licensed under a Creative Commons Attribution 3.0 License. 